\title{
TINJAUAN SYARIAH TERHADAP STRATEGI PEMASARAN PRODUK AKAD MUDHARABAH DI BMT DANA MENTARI KARANGLEWAS PURWOKERTO
}

\author{
Fatkhul Musobih ${ }^{1}$, Safitri Mukarromah ${ }^{2}$ \\ 1Universitas Muhammadiyah Purwokerto, Email : safitrimukarromah9@gmail.com \\ ${ }^{2}$ Universitas Muhammadiyah Purwokerto, Email : fatkhul.mushobih@gmail.com
}

\begin{abstract}
ABSTRAK
Artikel ini bertujuan untuk mengetahui produk dengan akad mudharabah, strategi pemasaran, dan aspek-aspek syariah terhadap produk di BMT Dana Mentari Karanglewas Purwokerto.. Jenis penelitian adalah penelitian lapangan dengan teknik pengumpulan data melalui observasi, wawacara, dan dokumentasi. Hasil penelitian ini menunjukkan bahwa produk dengan akad mudharabah pada BMT Dana Mentari Karanglewas Purwokerto yaitu produk simpanan dan pembiayaan. Strategi pemasaran BMT Dana Mentari dengan jemput bola dan service excellent. Strategi tersebut sangat efektif dalam pelayanan terhadap para anggota/nasabah karena sangat memudahkan dan memuaskan kebutuhan akan pelayanan yang baik bagi nasabah. Selain itu untuk meningkatkan dan memperluas penyaluran produk-produk BMT Dana Mentari juga melakukan kegiatan promosi melalui periklanan di internet, brosur, banner dan juga melalui kegiatan sosial yang rutin dilakukan setiap bulan pada awal pekan. Strategi pemasaran yang dilakukan oleh BMT Dana Mentari telah memuat aspek-aspek syariah dengan menerapkan cara berbisnis Nabi Muhammad Saw yaitu Shiddiq (benar dan jujur), Amanah (dapat dipercaya), Fathanah (cerdas), dan Tabligh (komunikatif)

Kata-kata kunci : Syariah; Strategi Pemasaran, Produk; Mudharabah
\end{abstract}

\begin{abstract}
This article aims to find out products with mudharabah contracts, marketing strategies, and sharia aspects of products in the BMT Dana Mentari Karanglewas Purwokerto. This type of research is field research with data collection techniques through observation, interview, and documentation. The results of this study indicate that products with mudharabah contracts on the BMT Dana Mentari are savings and financing products. Marketing strategy of BMT Dana Mentari by picking up the ball and service excellent. This strategy is very effective in service to members/customers because it greatly facilitates and satisfies the need for good service for customers. In addition to increasing and expanding the distribution of BMT Dana Mentari products also conduct promotional activities through advertising on the internet, brochures, banners and also through social activities that are routinely carried out every month at the beginning of the week. The marketing strategy carried out by BMT Dana Mentari has included aspects of sharia by applying the business methods of the Prophet Muhammad, namely Siddiq (true and honest), Amanah (trustworthy), Fathanah (intelligent), and Tabligh (communicative)
\end{abstract}

Keywords : Sharia; Marketing Strategy, Products; Mudharabah 


\section{PENDAHULUAN}

Institusi keuangan belum dikenal secara jelas dalam sejarah Islam. Namun prinsip-prinsip pertukaran dan pinjam-meminjam sudah ada dan banyak terjadi pada zaman Nabi Muhammad SAW. Tidak dipungkiri bahwa kemajuan pembangunan ekonomi dan perdagangan telah mempengaruhi lahirnya institusi yang berperan dalam lalu lintas keuangan. Para pedagang dan pengusaha sudah tidak mungkin lagi mengurusi keuangannya secara sendiri. (Ridwan, 2004: 52). Praktik ekonomi syariah pertama kali pada dasarnya terjadi bersamaan dengan lahirnya ajaran Islam pada abad VII masehi dengan mengacu pada perbuatan yang dilakukan oleh Nabi Muhammad SAW dan para sahabatnya. Pada masa kejayaannya sarrafs (semacam lembaga keuangan) mampu memenuhi harapan masyarakat dan menunjukkan kinerja yang baik dengan keterbatasan teknologi yang ada pada waktu itu. Sarrafs telah menilai keauntentikan dan keabsahan uang logam mulia. Sarrafs juga melakukan transfer dana dari satu tempat ke tempat lainnya tanpa adanya perpindahan dana secara fisik, serta menjamin keamanan dan kelancaran sistem pembayaran. Sarrafs dapat menjadi tempat untuk mencairkan check, juga bisa menerbitkan promissory notes dan LC (Letters of Credit). Sarrafs bertindak sebagai lembaga intermediasi keuangan dengan cara mobilisasi dana masyarakat, kemudian menyalurkannya kepada para produsen dan pedagang dengan akad mudharabah dan musyarakah. (Hulam, 2010: 4).

Lembaga keuangan telah berperan besar dalam pengembangan dan pertumbuhan masyarakat industri modern. Produksi secara besar dengan kebutuhan investasi yang membutuhkan modal yang besar tidak mungkin dipenuhi tanpa bantuan lembaga keuangan. Bank syariah merupakan bank yang secara operasional berbeda dengan bank konvensional. Salah satu ciri khas bank syariah yaitu tidak menerima atau membebani bunga kepada nasabah, tetapi menerima atau membebankan bagi hasil serta imbalan lain sesuai dengan akad-akad yang diperjanjikan. Konsep dasar bank syariah didasarkan pada al-Qur'an dan hadits. Semua produk dan jasa yang ditawarkan tidak boleh bertentangan dengan isi al-Qur'an dan hadits. (Ismail, 2011: 29-30). Pendirian bank syariah di Indonesia dimulai pada tahun 1992 dengan berdirinya Bank Muamalat Indonesia (BMI) sebagai bank Islam pertama yang beroperasi sesuai dengan prinsip syariah di 
Indonesia. Pendirian bank muamalat ini diikuti oleh Bank Pembiayaan Rakyat Syariah (BPRS). Lembaga ini masih dirasakan kurang mencukupi dan belum sanggup menjangkau masyarakat Islam lapisan bawah (Danupranata, 2013: 32).

Perkembangan perbankan syariah mendorong munculnya lembaga keuangan syariah alternatif lainnya, yakni sebuah lembaga yang tidak saja berorientasi bisnis tetapi juga sosial. Dan lembaga yang tidak melakukan pemusatan kekayaan pada sebagian kecil orang, tetapi lembaga yang kekayaannya terdistribusi secara merata dan adil. Lembaga yang terlahir dari dari kesadaran umat dan "ditakdirkan" untuk menolong kelompok mayoritas yakni pengusaha kecil/mikro. Lembaga yang tidak terjebak pada pikiran pragmatis tetapi memiliki konsep idealis yang istiqomah. Lembaga tersebut adalah Baitul Maal Wa Tamwil (BMT). Peran BMT dalam menumbuhkembangkan usaha mikro dan kecil di lingkungannya merupakan sumbangan yang sangat berarti bagi pembangunan nasional. Bank yang diharapkan mampu menjadi perantara keuangan ternyata hanya mampu bermain pada level atas. Sementara lembaga keuangan non formal yang notabene mampu menjangkau pengusaha mikro, tidak mampu meningkatkan kapitalisasi usaha kecil. Maka BMT diharapkan tidak terjebak pada dua kutub sistem ekonomi yang berlawanan tersebut. BMT tidak digerakkan dengan motif laba semata, tetapi juga motif sosial. Karena beroperasi dengan pola syariah, sudah barang tentu mekanisme kontrolnya tidak saja dari aspek ekonomi saja atau kontrol dari luar tetapi agama atau akidah menjadi faktor pengontrol dari dalam yang lebih aman. (Ridwan, 2004: 72-74).

BMT merupakan lembaga keuangan syariah yang pada praktiknya memiliki fungsi untuk mengorganisasi, mendorong serta mengembangkan kemampuan potensi anggota. BMT juga memiliki peran untuk meningkatkan kualitas SDM anggotanya juga berperan aktif memobilisasi potensi masyarakat untuk meningkatkan kesejahteraan anggota, baik pihak pemilik dana (shohibul maal) dan pengguna dana (mudharib) dalam pengembangan usahanya. Perkembangan BMT semakin pesat di Indonesia, salah satu diantara ratusan BMT yang berdiri yaitu BMT Dana Mentari di Purwokerto. BMT Dana Mentari menawarkan berbagai macam produk dan layanan. Produk dan pelayanan yang ada di BMT Dana Mentari secara umum yaitu produk akad murabahah, ijaroh, mudharabah,musyarakah, gard 
dan rahn. Istilah akad dalam hukum indonesia disebut dengan perjanjian. Akad adalah suatu perbuatan kesepakatan antara seseorang atau beberapa orang lainnya untuk melakukan suatu perbuatan tertentu. Terdapat beberapa jenis akad pada bank syariah diantaranya akad murabahah, akad salam, akad salam, akad wadiah, akad musyarakah, akad istishna, dan akad mudharabah.

Mudharabah adalah salah satu akad kerja sama suatu usaha antara pihak ertama shahibul maal (bank syariah) yang menyediakan seluruh modal dan pihak kedua mudharib (nasabah) yang bertindak sebagai pengelola dana dengan membagi keuntungan usaha sesuai dengan kesepakatan yang dituangkan dalam akad, sedangkan kerugian ditanggung sepenuhnya oleh bank syariah kecuali jika pihak kedua melakukan kesalahan yang disengaja, lalai atau menyalahi perjanjian. (Pradana, 2014:3).

Pentingnya dilakukan penelitian mengenai akad mudharabah pada Bank Syariah yaitu untuk memberikan kemudahan antara shahibul maal dan mudharib. Dengan demikian terdapat beberapa penelitian yang telah dilakukan sebelumnya berkaitan dengan akad mudharabah, diantaranya yaitu: pertama, Yesi Oktriani (2008) dengan judul "Pengaruh Pembiayaan Musyarakah, Mudharabah, dan Murabahah Terhadap Profitabilitas". Kedua Yana Rohayati (2010) dengan judul "Evaluasi Akuntansi Praktik Penghimpunan Dana Mudharabah dan Pembiayaan Murabahah di BMT Jepara Terkait Dengan Penerapan PSAK NO.59 Tahun 2003". Ketiga Zurrahmah Arif (2011) dengan judul "Tinjauan Fiqh Muamalat Terhadap Pelaksanaan Pembiayaan Mudharabah untuk Sektor Pertanian di BPRS Al-Barokah Depok". Keempat, Novia Rosi Nurjannah (2015) dengan judul "Analisis Kontribusi Pembiayaan Mudharabah dan Murabahah Terhadap Pendapatan Operasional Bank Syariah dari Sisi Kinerja Keuangan dan Penerapan PSAK 105 dan PSAK 102". Kelima, Asep Hilman Nuryaman (2017) dengan judul "Analisis Status Ganda Lembaga Intermediasi Keuangan Perbankan Syariah dalam Menjalankan Akad Mudharabah Menurut Perspektif Hukum Ekonomi Syariah".

\section{METODE PENELITIAN}

Jenis penelitian adalah penelitian lapangan (Field Research) yaitu penelitian yang mencari data secara langsung ke lapangan, dalam hal ini 
akan dilakukan di BMT Dana Mentari Karanglewas Purwokerto. Cara atau teknik menunjuk satu kata yang abstrak dan tidak diwujudkan dalam benda, tetapi hanya dapat dilihatkan penggunaanya melalui wawancara, dokumentasi dan lainnya (Riduwan,2007:24). Adapun teknik pengumpulan data dalam penelitian ini adalah observasi, wawacara, dan dokumentasi. Penulis mengolah dan menganalisis data secara kualitatif tanpa menggunakan teknik kuantitatif. Analisis kualitatif merupakan suatu teknik yang menggambarkan dan menginterpretasikan arti data-data yang telah terkumpul dengan memberikan perhatian dan merekam sebanyak mungkin aspek situasi yang diteliti pada saat itu, sehingga memperoleh gambaran secara umum dan menyeluruh tentang keadaan sebenarnya.

\section{HASIL DAN PEMBAHASAN}

BMT Dana Mentari Purwokerto berdiri pada tahun 1995 bersamaan dengan bermunculannya BMT di Indonesia. Salah satu diantara ratusan BMT yang berdiri adalah BMT yang terbentuk dari sekumpulan pemuda-pemudi Muhammadiyah yang bekerja sama dengan YBMM (Yayasan Baittul Maal Muhammadiyah) dengan tim pendiri yakni Achmad Sobirin, M. Sutopo Aji, Waryoto, Khomsahtun, Sudiro Husodo, dan Nanang Yulianto. Keenam pemuda ini saling bekerja sama dalam proses pendirian BMT Dana Mentari Muhammadiyah Purwokerto. M.Sutopo Aji, Nanang Yulianto dan Sudiro Husodo melakukan negosiasi ke Pimpinan Cabang Muhammadiyah (PCM) Purwokerto Barat, selaku tuan rumah yang nantinya ketempatan kantor, serta aturan/prosedur dari YBMM bahwa BMT harus di bawah naungan PCM, sementara Sobirin dan Khomsahtun melaksanakan tugas magang ke BMT Khairu Ummah Leuwiliang Bogor atas rekomendasi dari YBMM Pusat. Setelah melakukan magang, kemudian mendapatkan Surat Keputusan dari YBMM tentang pengesahan BMT Dana Mentari dibawah binaan YBMM tersebut, maka tim pendiri sepakat melakukan jadwal peresmian dan disepakati akan dilaksanakan pada hari Ahad, 01 Oktober 1995. Beberapa persiapan administrasi dilaksanakan oleh $\mathrm{M}$. Sutopo Aji diantaranya mengundang unsur-unsur PCM, PDM dan menembus maka dilaksanakanlah Acara Peresmian/Grand Opening BMT Dana Mentari PCM Purwokerto Barat yang secara simbolis diresmikan oleh Ketua PDM Banyumas.

Dalam perjalanannya pengurus mendapat dukungan dan 
pembinaan Dompet Dhuafa Republika yang waktu itu merangkul BMT Dana Mentari dengan mengajak kerjasama dalam hal Tebar Hewan Kurban dan pelatihan-pelatihan dan training bagi manajer dan karyawan. Setelah berjalan hampir dua tahun pengurus berfikir untuk membuat Badan Hukum/Legalitas Usaha yang waktu itu ada beberapa alternatif yaitu PT, $\mathrm{CV}$, atau Koperasi. Dari ketiga bentuk itu alternatif termudah adalah Koperasi. Maka pengurus pun tergerak untuk mengurus legalitas melalui Dinas Koperasi dan resmilah terbentuk Koperasi dengan Nama KSU (Koperasi Serba Usaha Dana Mentari) dengan SK Dari kemenkop. Produk-produk BMT-KSU Dana Mentari Muhammadiyah Karang Lewas Purwokerto. produk-produk dan layanan di BMT Dana Mentari Karanglewas Purwokerto yaitu:

1. Simpanan
a. Simpanan Umat
b. Simpanan Pendidikan
c. Simpanan Persiapan Qurban
d. Simpanan Walimah
e. Simpanan Hari Tua
f. Simpanan Haji / Umroh
g. Simpanan Ibu Bersalin
h. Simpanan Berjangka
i. Simpanan Wadiah dan ZIS

1) Simpanan Wadiah Yad Dhommanah

2) Zakat, Infak, dan Shadaqah (ZIS)

2. Pembiayaan

a. Pembiayaan Murabahah (Jual Beli)

b. Pembiayaan Mudharabah (Bagi Hasil)

c. Pembiayaan Ijarah (Sewa Beli)

d. Pembiayaan Musyarakah

e. Pembiayaan Rahn (Gadai Syariah)

f. Pembiayaan $\mathrm{Al}$ Qardh (Pinjam Meminjam)

3. Pelayanan Lain-Lain
a. Listrik/Token
b. Telkom
c. PDAM
d. Cicilan kendaraan (WOM, BAF, MCF, MAF) 
e. Penjualan Pulsa (All Operator)

f. Penjualan Tiket Kereta Api

g. Penjualan Tiket Pesawat (dalam dan luar negeri).

Produk dengan akad mudharabah yaitu ada pada produk simpanan dan pembiayaan mudharabah. Sementara produk simpanan mudharabah terbagi 4 bagian sebagai berikut :

1. Simpanan pokok khusus. Adalah uang yang dibayar oleh anggota pendiri dengan jumlah maksimalnya sesuai dengan kesanggupan anggota masing-masing. Simpanan ini dapat dibayar tunai atau cicilan ssuai dengan kesepakatan rapat anggota. Simpanan pokok khusus boleh dialihkan ke anggota lain, namun tidak boleh diambil.

2. Simpanan pokok. Adalah uang yang dibayar oleh setiap anggota BMT yang jumlahnya ditentukan dalam anggaran dasar. Simpanan pokok dapat dibayar tunai atau diangsur beberapa kali sesuai dengan anggaran dasar. Simpanan pokok ini merupakan tanda keanggotaan BMT. Oleh karena itu simpanan pokok tidak boleh diambil kecuali setelah anggota yang bersangkutan memutuskan untuk keluar dari keanggotaan BMT. Jumlah simpanan ini ditetapkan tidak terlalu tinggi sehingga masyarakat mudah untuk menjadi anggota BMT. Namun tidak pula terlalu rendah, sehingga nilainya dapat memiliki arti bagi modal BMT.

3. Simpanan wajib. Adalah uang yang dibayar oleh anggota BMT secara teratur dalam waktu tertentu, umpamanya seminggu sekali atau sebulan sekali, jumlahnya ditentukan dalam anggaran dasar. Dalam menetapkan jumlah simpanan wajib ini ditentukan sesuai dengan kemampuan anggota. Kedisiplinan anggota untuk membayar simpanan wajib merupakan ukuran loyalitas anggota terhadap BMT. Simpanan wajib tidak bisa diambil kecuali pada suatu waktu dimana modal di BMT sudah cukup banyak, maka setiap anggota boleh mengambil simpanan wajib dalam jumlah tertentu.

4. Simpanan sukarela. Adalah simpanan dalam berbagai bentuk produk simpanan yang dikembangkan oleh BMT Dana Mentari seperti simpanan ummat, simpanan pelajar, simpanan qurban, simpanan aqiqah, simpanan idul fitri, simpanan ukhuwah, simpanan hari tua, simpanan haji, simpanan ibu bersalin, simpanan pembiayaan dan simpanan penyertaan. 
Produk mudharabah di BMT Dana Mentari Karanglewas Purwokerto selain simpanan mudharabah ada pula pembiayaan mudharabah. Produk pembiayaan mudharabah di BMT terdiri dari pembiayaan mudharabah mutlaqah dan pembiayaan muqayyadah. Berdasarkan wawancara dengan manager marketing produk pembiayaan mudharabah di BMT Dana Mentari Karanglewas Purwokerto yang paling diminati oleh para anggota (nasabah) yaitu produk pembiayaan mudharabah mutlaqah, karena produk ini memberikan kebebasan kepada pengelola dana dalam menjalankan usahanya sesuai dengan peluang bisnis yang ada. Yang artinya dalam akad tersebut tidak ada batasan tertentu, baik dalam suatu jenis usaha, daerah bisnis, waktu usaha maupun lain-lain.

Strategi pemasaran produk dengan akad mudharabah di BMT Dana Mentari Karanglewas Purwokerto merupakan salah satu kegiatan perusahaan yang menjadi suatu ciri dari kegiatan usahanya. Bauran pemasaran atau marketing mix (4p) yaitu product, price, place, promotion yang dilakukan oleh BMT Dana Mentari untuk menarik minat nasabah yaitu:

1. Strategi produk (product). Adalah segala sesuatu yang dapat ditawarkan kedalam pasar untuk dapat diperhatikan, dimiliki, dipakai atau dikonsumsi sehingga dapat memuaskan keinginan atau kebutuhan. (Syauqi, 2016: 47-50). Strategi pemasaran produk yang dilakukan BMT Dana Mentari Karanglewas Purwokerto adalah mengdepankan kualitas yang terbaik dari tiap-tiap produk yang ditawarkan. Khususnya produk mudharabah yang ada di BMT banyak diminati karena nisbah bagi hasil yang lumayan besar dibandingkan dengan perbankan sehingga banyak yang tertarik menggunakan produk mudharabah di BMT Dana Mentari Karanglewas Purwokerto.

2. Strategi harga (price). Adalah menetapkan harga tertentu maka terbentuklah citra atau image tertentu dari konsumen kepada perusahaan. Strategi pemasaran harga yang dilakukan BMT Dana Mentari Karanglewas Purwokerto yaitu dengan menawarkan produk simpanan mudharabah yang mempunyai keunggulan tersendiri dari aspek bagi hasil yang cukup tinggi dibandingkan perbankan dan dana yang terkumpul bisa diambil sewaktu-waktu sesuai dengan kehendak anggota (nasabah). BMT tidak semata-mata mencari keuntungan dari anggota (nasabah) namun juga memelihara serta memperhatikan kemaslahatan anggota nasabah dengan melakukan pelayanan yang 
terbaik. Hal tersebut akan membentuk image yang bagus dimata nasabah mengenai BMT Dana Mentari Karanglewas Purwokerto.

3. Strategi tempat atau distribusi (place). Adalah kegiatan penyampaian produk sampai ke tangan konsumen pada waktu yang tepat. Kebijakan distribusi merupakan salah satu kebijakan pemasaran terpadu yang mencakup penentuan saluran pemasaran (marketing channeles) dan distribusi fisik (physichal distribution). (Syauqi, 2016: 47-50). BMT Dana Mentari Karanglewas Purwokerto merupakan kantor pusat BMT Dana Mentari yang tersebar di area Purwokerto yaitu di Karangwangkal, Pasar pon, Kembaran dan Cilongok. Strategi pemasaran pemilihan tempat yang dilakukan manajemen BMT Dana Mentari membidik ditempat perputaran uang berlangsung misalnya dekat pasar dan juga sekolah maupun kampus karena lebih menjanjikan. Yang membidik dekat pasar yaitu cabang Pasar Pon, Cilongok, Kembaran serta Karanglewas itu sendiri, dan yang dekat dengan kampus yaitu cabang karangwangkal. Dengan itu menunjukan strategi pemasaran yang dilakukan oleh BMT Dana Mentari membidik tempat perputaran uang berlangsung seperti yang sudah dijelaskan di atas.

4. Strategi promosi (promotion). Adalah suatu usaha peningkatan penjualan perusahaan menjalankan berbagai hal seperti memperbaiki dan memperluas penyaluran produknya serta meningkatkan pelayanan pada konsumen. (Syauqi, 2016: 47-50). BMT Dana Mentari Karanglewas Purwokerto melakukan strategi promosi dengan cara sebar brosur, banner, promosi di internet dan promosi secara langsung di sekolah-sekolah, pasar dan masyarakat. BMT Dana Mentari setiap bulan melakukan pertemuan kepengurusan yang dilakukan pada awal pekan yang dengan tujuan untuk mempromosikan produk BMT kepada masyarakat dan juga bertujuan untuk mengadakan bakti sosial dengan membagikan nasi kotak dan juga mengadakan pengajian di masyarakat.

Terlepas dari komponen bauran pemasaran (marketing mix), dari sisi operasional pun turut berperan proaktif dalam pemasaran produk-produk mudharabah di BMT Dana Mentari Karanglewas Purwokerto. Misalkan costumer service dan teller bertanggung jawab untuk melayani sekaligus memasarkan produk dengan mengutamakan nasabah yang datang ke BMT. Dalam hal pemasaran di luar kantor marketing yang 
bertanggungjawab melayani, memelihara, dan juga merawat para anggota/nasabah dengan baik. BMT menanamkan bahwa mereka adalah lembaga dari, oleh dan untuk umat. BMT mengedepankan pelayanan dengan mengusung pemasaran produk dengan cara jemput bola dan juga service excellent yang merupakan upaya BMT dalam melayani anggotanya dengan baik. Sistim jemput bola merupakan layanan yang ditawarkan oleh BMT untuk mempermudah nasabah yang membuka tabungan maupun penyetoran tabungan dengan didatangi oleh marketing sehingga nasabah tidak harus datang ke BMT namun bisa terlayani dengan baik oleh marketing. Sasaran dari layanan jemput bola ini adalah mayarakat umum khususnya masyarakat kecil, instansi-instansi dan lainnya yang merupakan calon nasabah dan nasabah. Dengan adanya layanan jemput bola ini terbukti meningkatkan dan menarik nasabah untuk menjadi anggota di BMT.

Service excellent atau Service excellence juga merupakan bentuk layanan yang ditawarkan oleh BMT Dana Mentari selain jemput bola. Service excellent merupakan bentuk pelayanan oleh pengelola baik teller, customer service, dan marketing harus mampu berkomunikasi baik dengan bersikap ramah, santun dalam tutur kata dan juga cekatan sehingga nasabah pun merasa nyaman dan terlayani. Layanan secara langsung terbukti sangat efektif dalam strategi guna mempromosikan produk-produk yang ada di BMT. BMT mempromosikannya melalui beberapa aspek masyarakat baik dalam sektor perdagangan maupun dalam sektor pelajar di sekolah-sekolah yang dekat dengan BMT. Promosi yang dilakukan di dalam sekolah juga berdampak positif bagi para pelajar karena disamping mereka bisa menabungkan uang di BMT, mereka pun mendapatkan materi lewat seminar yang diadakan didalam sekolahan dari pihak BMT sehingga bisa mewujudkan kemaslahatan umat dalam bidang pendidikan. Hal tersebut juga menjadikan BMT sangat dikenal oleh masyarakat dan terus tumbuh berkembang dalam lembaga keuangan syariah di Indonesia.

Service excellent yang diterapkan oleh BMT Dana Mentari sangat berdampak positif, karena para anggota/ nasabah merasa di mudahkan, dilayani dan nyaman menjadi bagian dari anggota BMT Dana Mentari. Hal tersebut diperoleh karena profesionalitas pengurus BMT Dana Mentari dalam melayani para anggotanya, karena di BMT Dana Mentari kepuasan anggota adalah prioritas utama. Dengan demikian dapat disimpulkan 
strategi pemasaran yang diterapkan BMT Dana Mentari dengan menggunakan sistem jemput bola dan service excellent sangat efektif dalam menarik minat masyarakat baik yang sudah atau belum tergabung menjadi anggota di BMT Dana Mentari Karanglewas Purwokerto.

Penerapan strategi pemasaran yang baik adalah pemasaran yang dilakukan sesuai dengan ketentuan syariat Islam. Menurut AD Porwaningtyas (2009) strategi pemasaran dalam Islam:

1. Shiddiq. Sifat shiddiq dapat diartikan jika seorang pengusaha senantiasa berperilaku benar dan jujur dalam sepanjang kegiatannya, jika seorang pemasar bersifat shiddiq haruslah menjiwai seluruh perilakunya dalam melakukan pemasaran, dalam berhubungan dengan pelanggan, dalam bertransaksi dengan nasabah, dan dalam membuat perjanjian dengan mitra bisnisnya. Kegiatan promosi yang dilakukan BMT Dana Mentari Karanglewas Purwokerto yaitu melalui periklanan seperti brosur, spanduk, di internet, serta promosi secara langsung. Di mana dalam mempromosikan jasa serta produk-produk tersebut dari pihak BMT memberikan informasi yang benar adanya tanpa unsur penipuan.

2. Amanah. Bermakna dapat dipercaya, bertanggung jawab, dan kredibel, juga bermakna keinginan untuk memenuhi sesuatu sesuai dengan ketentuan. Acuan strategi pemasaran yang dilakukan oleh BMT Dana Mentari Karanglewas Purwokerto agar senantiasa amanah bersikap terbuka dengan nasabah sehingga selalu menjadi lembaga keuangan yang terpercaya di mata nasabah. Dengan melihat perkembangan minat masyarakat untuk menjadi anggota BMT Dana Mentari, disini mencerminkan rasa percaya yang tinggi dari nasabah terhadap BMT Dana Mentari. Itulah mengapa produk-produk yang ditawarkan BMT Dana Mentari sangat diminati nasabah dan produk simpanan Umat dengan akad mudharabah menjadi salah satu produk yang paling diminati oleh nasabah karena BMT Dana Mentari Karanglewas Purwokerto telah mendapatkan kepercayaan yang tinggi dari para anggotanya.

3. Fathanah. Diartikan sebagai intelektual, kecerdikan atau kebijaksanaan. Pemimpin yang fathanah adalah pemimpin yang memahami, mengerti, dan menghayati secara mendalam segala hal yang menjadi tugas dan kewajibannya. Strategi pemasaran yang dilakukan oleh BMT Dana 
Mentari Karanglewas Purwokerto dengan berlandaskan sifat fathanah yaitu BMT bertujuan tidak semata-mata beorientasi bisnis untuk mencari keuntungan financial disektor perbankan, tetapi disertai dengan kegiatan sosial dengan memberikan sedikit dakwah dibidang ekonomi (maaliyah) secara syariah dengan mengadakan semacam presentasi kepada lembaga seperti di sekolah-sekolah yang sudah memberikan izin kepada BMT Dana Mentari. Sehingga BMT Dana Mentari turut berperan mencerdaskan masyarakat dengan memberikan sedikit pengetahuan mengenai ekonomi syariah, disini dapat menjelaskan bahwa BMT Dana Mentari sebagai lembaga keuangan syariah yang dapat memahami, mengerti, dan menghayati secara mendalam segala hal yang menjadi tugas dan kewajibannya. Dalam bisnis, implikasi ekonomi sifat fathanah bahwa segala aktivitas dalam manajemen suatu perusahaan harus dengan kecerdasan, dengan mengoptimalkan semua potensi akal yang ada untuk mencapai tujuan. BMT Dana Mentari telah melakukan tugas sebagai lembaga keuangan syariah dengan melakukan promosi dan BMT Dana Mentari pun tak melupakan kewajiban sesama umat dengan turut mencerdaskan masyarakat dengan strategi pemasaran yang dilakukannya.

4. Tabligh. Diartikan sebagai komunikatif dan argumentatif dengan tutur kata yang tepat dan mudah dipahami. Dalam bisnis, haruslah menjadi seorang yang mampu mengomunikasikan visi dan misinya dengan benar kepada karyawan dan stakeholder lainnya. Juga menyampaikan keunggulan-keunggulan produknya dengan jujur dan tidak harus berbohong maupun menipu pelanggan. BMT Dana Mentari Karanglewas Purwokerto yang merupakan lembaga keuangan syariah yang telah lama berdiri sejak tahun 1995 mencerminkan bahwa BMT Dana Mentari mampu bersaing dengan lembaga keuangan lainnya. Hal tersebut tak lepas dari strategi pemasaran BMT Dana Mentari yang komunikatif dalam menawarkan produk-produk dan pelayanan yang bisa diterima, baik untuk mencari calon anggota/nasabah maupun dalam membangun relasi yang baik dan merawat anggota yang telah menjadi anggota di BMT Dana Mentari. Dalam membangun relasi yang komunikatif tersebut tidak terlepas dari profesionalitas para penggurus di BMT Dana Mentari sehingga BMT Dana Mentari dapat terus bertahan dan terus berkembang dalam persaingan global yang terus meningkat dalam segala aspek di lembaga keuangan baik dalam 
perbankan maupun nonperbankan. Perkembangan BMT Dana Mentari tidak lepas dari strategi komunikatif yang baik tethadap nasabah sehingga BMT Dana Mentari menjadi mitra bisnis yang dibutuhkan oleh masyarakat, hal tersebut dapat dilihat dari meningkatnya anggota yang bergabung dengan BMT Dana Mentari khususnya pada produk simpanan umat yang menggunakan akad Mudharabah.

Tumbuh dan berkembangnya BMT Dana Mentari Karanglewas Purwokerto sangat tergantung pada kepercayaan dan motivasi masyarakat serta kemampuan profesionalisme pengelola BMT. Dengan melakukan pelayanan yang baik pihak BMT mampu membangun relasi yang kuat antara penggelola dan anggotanya, BMT bertujuan tidak semata-mata beorientasi bisnis untuk mencari keuntungan finansial disektor perbankan, melainkan terutama menjalankan dakwah dibidang ekonomi (maaliyah) secara syariah yang berpihak kepada rakyat kecil agar kemampuan usaha dan ekonominya dapat tumbuh dan berkembang berdasarkan prinsip syariah islam. Selain menawarkan produk simpanan dan juga pembiayaan BMT juga bisa menjadi tempat penyaluran dana zakat, infaq, dan shodaqah sehingga BMT juga berperan penting dalam kemaslahatan umat.

\section{SIMPULAN}

Produk dengan akad mudharabah pada BMT Dana Mentari Karanglewas Purwokerto yaitu produk simpanan dan pembiayaan. Produk simpanan berupa simpanan umat, simpanan pelajar, simpanan qurban, simpanan aqiqoh, simpanan idul fitri, simpanan ukhuwah, simpanan hari tua, simpanan haji, simpanan ibu bersalin, simpanan pembiayaan, simpanan penyertaan, simpanan pokok dan simpanan wajib. Produk pembiayaan berupa pembiayaan mudharabah mutlaqah dan mudharabah muqayyadah.

Strategi pemasaran BMT Dana Mentari Karanglewas Purwokerto yaitu dengan jemput bola dan service excellent. Strategi tersebut sangat efektif dalam pelayanan terhadap para anggota/nasabah karena sangat memudahkan dan memuaskan kebutuhan akan pelayanan yang baik bagi nasabah. Dalam distribusi BMT Dana Mentari Karanglewas Purwokerto melakukan survei langsung ke lapangan yang ditargetkan, seperti pasar, sekolah, perumahan serta masyarakat yang ingin menjadi anggota/nasabah di BMT Dana Mentari dengan produk-produk yang ditawarkan. Selain itu untuk meningkatkan dan memperluas penyaluran produk-produk BMT 
Dana Mentari juga melakukan kegiatan promosi melalui periklanan di internet, brosur, banner dan juga melalui kegiatan sosial yang rutin dilakukan tiap bulan pada awal pekan. Strategi pemasaran yang dilakukan oleh BMT Dana Mentari Karanglewas Purwokerto telah sesuai ke-syariahan, dengan menerapkan cara berbisnis Nabi Muhammad Saw yaitu Shiddiq (benar dan jujur), Amanah (dapat dipercaya), Fathanah (cerdas), dan Tabligh (komunikatif).

\section{DAFTAR REFERENSI}

A Karim, Adiwarman. (Ed.4). (2011). Bank islam: Analisis figh dan Keuangan. Jakarta: Rajawali Pers.

Antonio, M. Syafi'i. (2001). Bank Syariah Dari Teori ke Praktik. Jakarta: GemaInsani.

Arif, Zurrahmah. (2011). Tinjauan Figh Muamalat Terhadap Pelaksanaan Pembiayaan Mudharabah Untuk Sektor Pertanian di BPRS Al-Barokah. Jakarta: UIN Syarif Hidayatullah. http://repository.uinjkt.ac.id. Diakses pada tanggal 8 Maret 2018.

Danupranata, Gita. (2013). Buku Ajar Manajemen Perbankan Syariah. Jakarta Hulam, T. (2010). Jaminan Dalam Akad Mudharabah Pada Perbankan Syariah. Mimbar Hukum, 22(3), 520-533. http://eprints.walisongo.ac.id/1881/. Diakses pada tanggal 9 Februari 2018.

Hilman Nur, Asep. (2017) Strategi Analisis Status Ganda Lembaga Intermediasi Keuangan Perbankan Syariah dalam Menjalankan Akad Mudharavah Menurut Perspektif Hukum Ekonomi Syariah. Cirebon: Institut Agama Islam Nurjati. http://repository.syekhnurjati.ac.id. Diakses pada tanggal 8 Maret 2018.

Ilyas, Yunahar. (2015). Kuliah Akhlaq. Yogyakarta: LPPI.

Ismail. (2012). Perbankan Syariah, jakarta: Kencana

Jazuli, Syauqi. (2016). Analisis SWOT Strategi Pemasaran Produk Pembiayaan pada BMT El - Syifa Cigasur. Jakarta: Universitas Negeri Syarif Hidayatuallah. http://103.229.202.68. Diakses pada tanggal 8 Maret 2018

Kasmir. (2008). Pemasaran Bank. Jakarta: Media Grafika.

Mardani. (2012). Figh Ekonomi Syariah: Figh Muamalah. Jakarta: Prenada Media Group

Oktriani, Yesi.(2008). Pengaruh Pembiayaan musyarakah, Mudharabah, dan 
murabahah Terhadap Profitabilitas. Bandung: Universitas Siliangi. http://Skripsi.Universitas Siliwangi. Bandung, 2008 journal.unsil.ac.id. Diakses pada tanggal 8 Maret 2018.

Porwaningtyas, AD.(2009). Strategi Pemasaran dalam Islam. http://digilib.uinsby.ac.id Diakses pada tanggal 18 Juli 2018.

Pradana, Yurista. (2014). Analisis Pembiayaan Mudharabah dan Murabahah (Studi Kasus BRI Syariah Cabang Gubeng Surabaya). Jurnal Akuntansi UNESA 2.2 (2014). http://ejournal.unesa.ac.id. Diakses pada tanggal 12 Maret 2018.

Prasetyo, Luhur. (2010). Perkembangan Perbankan Syariah Pasca UU 21 Tahun 2008. Ponorogo: STAIN. http://jurnal.stainponorogo.ac.id. Diakses pada tanggal 8 Maret 2018.

Ridwan, Muhammad. (2004). Manajemen Baitul Maal Wa Tamwil. Yogyakarta: UII Press.

Riduwan. (2007). Skala Pengukuran Variable-variable Penelitian. Bandung : Alfabeta.

Rohayati, Yana. (2010). Evaluasi Akuntansi Praktik Penghimpunan Dana Mudharabah dan Pembiayaan Murabahahdi BMT Jepara Terkait Dengan Penerapan PSAK NO.59 Tahun 2003. Jepara: Sekolah Tinggi Ilmu Ekonomi Nahdlatul Ulama. http://eprints.unisnu.ac.id. Diakses pada tanggal 8 Maret 2018

Rosi Nurjannah, Novia. (2015). Analisis Kontribusi Pembiayaan Mudharabah dan Murabahah Terhadap Pendapatan Operasional Bank Syariah dari sisi kinerja Keuangan dan Penetapan PSAK 105 DAN PSAK 102.Malang: Universitas Maulana Ibrahim. http:/etheses.uin-malang.ac.id. diakses pada tanggal 8 Maret 2018.

Sarwani, Denny. (2015). Strategi Pemasaran Produk Tabungan Makmur Junior Bank Syariah Mandiri KCP Pondok Pinang. http://repository.uinjkt.ac.id diakses pada tanggal 12 Maret 2018.

Satori Djam'an. (2011). Metodologi Penelitian Kualitatif. Bandung: Alfabeta.

Sujarweni V. Wiratma. (2014). Metodologi Penelitian. Yogyakarta: Pustaka BaruPress.

Tjiptono, Fandy. (2002). Strategi Pemasaran. Yogyakarta: ANDI. www.danamentaripurwokerto.blogspot.com diakses pada 18 Juni 2018. 